\title{
Consumer Ethnocentrism, Demographic Characteristics and Willingness to Buy Commercial Banking Services in Kenya
}

\author{
Maina, S. M., PhD, Lecturer \\ Kenyatta University, School of Business, Department of Business \\ Administration.
}

doi: 10.19044/esj.2016.v12n25p306 URL:http://dx.doi.org/10.19044/esj.2016.v12n25p306

\begin{abstract}
International marketing empirical literature has indicated the existence and strength of relationships among the consumer ethnocentrism, demographic variables and product attitude vary in different market context. Subsequently consumer ethnocentrism and purchase intentions influence depends on the product categories and other market factors. It is on the basis of this premise that the current study embarked on assessing the moderating effect of demographic characteristics on the relationship between consumer ethnocentrism and willingness to buy banking services. Descriptive and explanatory research design were used in the study. Primary data was collected among 374 commercial banks account holders in Kenya. Data was analyzed using step wise binary logit regression. Consumer national ethnocentrism was found to have a negative influence on the willingness to buy banking services from foreign owned commercial banks. The assessment of the effect of demographic characteristics on willingness to buy commercial banking services revealed that as the levels of respondents' income per month increased, there was high preference of buying from foreign owned banks and vice versa. However age, gender and income do not moderate the relationship between consumer ethnocentrism and willingness to buy banking services. This indicate the essence of intergroup differentiation in service or market offerings as well as market segmentation and targeting.
\end{abstract}

Keywords: International marketing; Consumer ethnocentrism; demographic characteristics; willingness to buy

\section{Introduction}

The relative influence of demographic characteristics on consumption of financial services has been found to vary considerably from other consumer goods (Erdogan \& Uzkurt, 2010). In particular differences may be found when 
comparing consumers from less developed nations with those from more developed nations. Although this has not been established yet, the proposition can be supported by evidence on individual antecedents of consumer ethnocentrism. For instance, according to Chryssochoidis et al. (2007) consumer animosity effects exist at country, product, and attribute levels. Thus for consumers who are ethnocentric, the animosity effect usually becomes activated at the national level but not at the attributes or product levels. Further Chryssochoidis et al. (2007) asserted that if the foreign country of origin is known, the animosity effect for ethnocentric consumers gets activated at the product level. However for consumers who are not ethnocentric animosity does not lead to overall rejection or acceptance but rather influences evaluations of particular product attributes. Among the highly ethnocentric consumers, animosity cues normally have a relatively larger effect on product assessments and willingness to buy foreign products than it does on less ethnocentric consumers (Chattalas et al., 2008). Therefore based on previous empirical studies CET effect exists across different nations (Hamin \& Elliott, 2006). However the CET effect varies not only across nations but also across groups within the same country (Bandyopadhyay et al., 2011).

Wang and Chen, (2004) conducted a study in China and found that the effect of consumer ethnocentrism on willingness to buy domestic products tends to be weaker when consumers hold higher conspicuous consumption values. Similarly Josiassen, Assaf, and Karpen (2011) study in Australia found that age, gender, and income of consumers predicts the levels of consumer ethnocentrism. The extent to which these demographic factors moderate the influence of consumer ethnocentrism on willingness to buy foreign and domestic products or services is a major concern in this study.

\section{Consumer Demographic Characteristics}

Demographics can be defined as the quantifiable statistics of a given population in a specific location. In some cases, demographics are also used to identify the study of quantifiable subsets within a given population which characterize that population at a specific point in time (Power \& Elliott, 2006). Commonly examined demographics include age, race, gender, level of education, income level, disabilities, mobility, home ownership, employment status, among others. Studies related to both import purchasing behavior and consumer ethnocentrism take demographics of the respondents as a separate set of antecedents (Shankarmahesh, 2006). This presents an opportunity to the researcher of segmenting consumers according to their favorable and unfavorable preferences to foreign as well as domestic products or services.

Consumer demographic characteristics have been found to be vital while discussing the ethnocentric behavior of consumers (Good \& Huddleston, 1995). However there has been mixed results on how these 
factors influence ethnocentric tendencies. For instance, there seems to be more inclined empirical arguments which support that younger people are less ethnocentric when compared with older people (Klein \& Ettenson, 1999). Conversely other previous studies such as Sharma et al., (1995) did not find any statistically significant relationship between age and CET. Therefore there is a need for further inquiry and validation of such propositions.

\section{Willingness to Buy}

Morrison (1979) refers to purchase intents as outcomes of a stochastic process whose latent (unobserved) variable is the true purchase intent at the time of the survey. Intentions to perform a given behaviour are influenced by three key factors: a perceived social pressure to perform or not perform the behaviour (subjective norm); a favourable or unfavourable evaluation of the behaviour (attitude toward the behaviour); and self-efficacy in relation to the behaviour (perceived behavioural control) (Ajzen, 1987). Past studies used different constructs such as purchase intention, willingness to buy domestic products, and willingness to buy foreign products (Shankarmahesh, 2006).

The intention to adopt a certain course of action logically precedes actual performance of the behaviour (Ajzen, 1991). Hence individual level of discrepancies between purchase intent and behavior can be explained by a random change in true purchase intent after the survey as determined by an exogenous switching probability and/or the very nature of stated purchase intents and behavior variables. As such, it is necessary to understand the process followed in making purchase decisions and the main factors which influence the outcome of that decision for the final consumer. Therefore willingness to buy in the study comprised of the patron's preference or lack of preference of banking services from locally owned commercial banks. These measures were similar to those used previous service literature (Baker et al., 1992).

\section{Consumer Ethnocentrism, Demographic Characteristics and Willingness to buy Banking Services}

Empirically there has been mixed evidence on the influence of age on consumer's purchase intentions. For instance Balabanis et al. (2001) and Sharma et al. (1995) found that older consumers are more ethnocentric than younger consumers (Shankarmahesh, 2006). Conversely Bannister and Saunders (1978) and Schooler (1971) found that younger consumers are more ethnocentric than older consumers. Other studies that show positive relationships are Caruana and Magri, (1996) and Shimp and Sharma, (1987). The study by Josiassen et al. (2011) posited that older consumers have a tendency to be more ethnocentric than younger consumers. According to them, the results confirmed the theoretical foundation laid by Sharma et al. (1995) 
who found positive relationship between age and conservatism and that of Anderson and Cunningham (1972) who also found positive relationship between age and dogmatism. Conservatism and dogmatism act as antecedents to consumer ethnocentrism. But this deepened the controversies in this construct.

With respect to the effect of gender Schooler (1971) and Dornoff et al. (1974) found that women prefer products coming from abroad than men while McLain and Sternquist (1991) and Caruana, (1996) found no significant relationship between gender and willingness to buy. Other empirical and theoretical studies such as Bannister and Saunders (1978) and Shankarmahesh (2006) reported that men are more ethnocentric than women. However empirical evidence shows that women are more conservative and conformist (Han \& Terpstra, 1988) as well as collectively minded (Triandis et al., 1985) than men. Conservatism, conformism and collective mindedness in turn have been shown to be antecedents of consumer ethnocentrism (Nishina, 1990; Sharma et al., 1995) and hence affects consumer willingness to buy. Josiassen et al. (2011) found that ethnocentric tendencies are more prevalent among female consumers than among male consumers.

Subsequently empirical support in several studies seems to disagree on the proposition that an increase in income has negative or positive effects on the relationship between consumer ethnocentrism and willingness to buy. Studies that support negative relationship include Sharma et al. (1995) and Caruana, (1996). Those who found no effect include Han and Terpstra (1988) and Josiassen, et al. (2011) while those who reported positive relationship are Tan and Farley (1987) and Balabanis et al. (2001). Although there a number of demographics variables, the study only focused on those demographic antecedents where previous studies posited mixed results that is age, gender and income. This is depicted in figure 1.

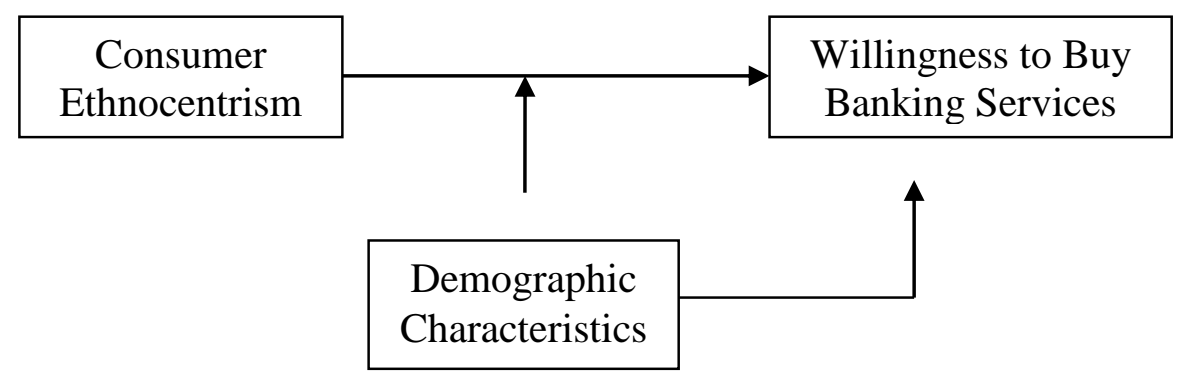

Figure 1 Conceptual Model

Based on the conceptual model (Figure 1) and the empirical review the following hypotheses were tested in the study:

$\mathrm{H}_{1}$ : Consumer ethnocentrism has significant influence on willingness to buy 
banking services.

$\mathrm{H}_{2}$ : consumer demographic characteristics have significant effect on the willingness to buy banking services.

$\mathrm{H}_{3}$ : Consumer demographic characteristics have significant moderating effect on the relationship between consumer ethnocentrism and willingness to buy banking services.

\section{Methodology}

\section{Study Design and Data Collection}

Descriptive and explanatory research design were used in the study. Descriptive design focused on examining the what and how of consumer behaviour in commercial banking sector. Explanatory design was used to explain the effect of consumer ethnocentrism and demographic characteristics on the willingness to buy banking services. The population of interest was the account holders in both the domestic and foreign commercial banks in Kenya. A sample of 374 was selected for the study using disproportionate stratified sampling plan. The researcher personally administered the questionnaires among the study respondents.

\section{Reliability and Validity of the Research Instruments}

The reliability test for consumer ethnocentrism (CETSCALE) had a Cronbach alpha coefficient $(\alpha)$ of 0.896 . Hence the result for the scale was higher than the general convention in research that has been prescribed by Nunnally and Bernstein (1994) who state that one should strive for reliability values of .70 or higher. The distinctiveness of the measure or construct validity for consumer ethnocentrism was examined through Confirmatory Factor Analysis (CFA). In this respect 55.3\% of the total variability of consumer ethnocentrism was found to be explained by three factors. The first factor which is consumer patriotism explained $23.1 \%$ of the total variability, while the second (consumer salience) and third (consumer animosity) explained $19.8 \%$ and $12.4 \%$ respectively. The results of KaiserMeyer-Olkin test was 0.897 and Bartlett's test of sphericity was statistically significant $(\alpha \leq 0.05)$.

\section{Data Analysis}

Both descriptive and inferential statistics were used. Descriptive statistics included cross tabulations and measures of variability. The purpose of categorizations and cross-tabulation was to allow the inspection of differences among groups and to make comparisons. This form of analysis helps determine the form of relationship between two variables. Hence critical aspects in the questionnaire were cross-tabulated with demographical questions in the questionnaire to determine the level of association. To test the 
relationships between the study variables, binary logistic regression analysis was used appropriately. Specifically binary logistic regression was used in the study to predict dichotomous outcome of willingness to buy (preference or no preference). Logistic regression uses maximum likelihood estimation to compute the coefficients for the logistic regression equation. To test the moderating effects the change in odds ratio attributable to the interaction terms added was examined (Keppel \& Zadeck, 1989). If they produced a significant odds ratio change in the criterion variable (willingness to buy anking services), the moderating effect was significant (Jaccard et al., 1990; Jaccard, 2001). The exponent function or odds ratio was used for interpretation.

\section{Empirical Results and Discussion}

\section{Respondents' Demographic Characteristics}

The analysis of general characteristics of the respondents is presented in Table 1. These include age, gender and level of income per month.

Table 1 Respondents' Demographic Characteristics

\begin{tabular}{|c|c|c|}
\hline Respondent's characteristics & Frequency & $\%$ \\
\hline \multicolumn{3}{|l|}{ Gender } \\
\hline Female & 186 & 49.7 \\
\hline Male & 187 & 50 \\
\hline Non response & 1 & 0.3 \\
\hline Total & 374 & 100 \\
\hline \multicolumn{3}{|l|}{ Age } \\
\hline $18-25$ years & 148 & 39.6 \\
\hline 26-32 years & 70 & 18.7 \\
\hline $33-40$ years & 70 & 18.7 \\
\hline Above 40 years & 85 & 22.7 \\
\hline Non response & 1 & 0.3 \\
\hline Total & 374 & 100 \\
\hline \multicolumn{3}{|l|}{ Level of income per month } \\
\hline Up to Ksh 10,000 & 73 & 19.5 \\
\hline Ksh $10,001-20,000$ & 31 & 8.2 \\
\hline Ksh 20,001-50,000 & 96 & 25.7 \\
\hline Ksh50,001-100,000 & 75 & 20.1 \\
\hline Above Ksh 100,001 & 50 & 13.4 \\
\hline Non response & 49 & 13.1 \\
\hline Total & 374 & 100 \\
\hline
\end{tabular}

Source: Primary Data

The results in Table 1 indicate that there was almost equal number of respondents from each gender: female (49.9\%) and male (50.1\%). Among those respondents $39.6 \%$ were between 18 and 25 years. This suggests that a 
large number of young people participated in the study. With respect to the level of income per month almost half $(45.8 \%)$ of the respondents earned between Kshs 20,000 and Kshs 100,000. To predict whether there existed any relationship among the demographic variables (gender, age and income) cross tabulations were conducted with reference to willingness to buy banking services. Table 2 shows the cross tabulation between gender and willingness to buy banking services.

Table 2 Respondents' Gender and their Willingness to Buy Banking Services

\begin{tabular}{|c|c|c|c|c|}
\hline & & \multicolumn{2}{|c|}{ Willingness to buy banking services } & \multirow{2}{*}{ Total (\%) } \\
\hline & $\mathrm{n}_{\mathrm{i}}$ & No Preference & Local preference & 100 \\
\hline Female & 167 & 47.9 & 52.1 & 100 \\
\hline Male & 170 & 53.5 & 46.5 & 100 \\
\hline Total & 337 & 50.7 & 49.3 & \\
\hline
\end{tabular}

Source: Primary Data

As shown in Table 2 women were more ethnocentric than men since $52.1 \%$ preferred services from locally owned commercial banks. This is contrary to other studies such as Bannister and Saunders, (1978) and Shankarmahesh, (2006) who found men to be more ethnocentric than women. Table 3 presents the results between age and willingness to buy banking services.

Table 3 Respondents' Age and their Willingness to Buy Banking Services

\begin{tabular}{|c|c|c|c|c|}
\hline & & \multicolumn{2}{|c|}{ Willingness to Buy banking services } & \multirow{2}{*}{$\begin{array}{c}\text { Total } \\
(\%)\end{array}$} \\
\hline 18-25 years & 136 & $\mathrm{n}_{\mathrm{i}}$ & $\begin{array}{c}\text { Local } \\
\text { preference }\end{array}$ & 100 \\
\hline 26-32 years & 60 & 43.7 & 46.3 & 100 \\
\hline 33-40 years & 62 & 41.9 & 51.7 & 100 \\
\hline Above 40 years & 79 & 54.4 & 58.1 & 100 \\
\hline Total & 337 & 50.7 & 45.6 & 100 \\
\hline
\end{tabular}

Source: Primary Data

With respect to age distribution Table 3 reveals that as respondent advances in age the ethnocentric tendency also increases. However, the ethnocentric tendencies decrease among respondents who were above 40 years. Based on these observations the older people appear to be more ethnocentric than the younger ones. This observation is inconsistent with Bannister and Saunders (1978) and Schooler (1971). The cross tabulation between the level of income per month and willingness to buy banking services are presented in Table 4.

Table 4 Respondents' Level of Income per Month and their Preferences

\begin{tabular}{|c|c|c|c|c|}
\hline & & \multicolumn{2}{|c|}{ Willingness to Buy banking services } & Total \\
\cline { 1 - 4 } & $\mathrm{n}_{\mathrm{i}}$ & No Preference & Local preference & $(\%)$ \\
\hline Up to Ksh 10,000 & 68 & 47.1 & 52.9 & 100 \\
\hline Ksh 10,001-20,000 & 30 & 56.7 & 43.3 & 100 \\
\hline Ksh 20,001-50,000 & 88 & 48.9 & 51.1 & 100 \\
\hline
\end{tabular}




\begin{tabular}{|c|c|c|c|c|}
\hline Ksh50,001-100,000 & 69 & 46.4 & 53.6 & 100 \\
\hline Above Ksh 100,001 & 44 & 65.9 & 34.1 & 100 \\
\hline Total & 299 & 51.2 & 48.8 & 100 \\
\hline
\end{tabular}

Source: Primary Data

It is discernible from Table 4 that there was no major difference with respect to respondents' preference based on level of income. However those who preferred banking services from locally owned banks were slightly less than those who had no preference.However most of the respondents had multiple accounts in different banks.

Table 5 Types of Banking Services Bought

\begin{tabular}{|c|c|c|c|}
\hline & \multicolumn{2}{|c|}{ Responses } & Multiple responses \\
$(\%)$
\end{tabular}

Source: Primary Data

The results in Table 5 reveal that the highly bought services were withdrawals and deposits. However most of the respondents bought an assortment of services.

\section{Responses on Willingness to Buy Banking Services}

To measure willingness to buy banking services the respondents were asked to choose their preference based on their overall assessments of where to buy their banking services given the choice of locally owned banks, foreign owned banks, both or none. The results are presented in Table 6 .

Table 6 Responses on Consumer Preferences Based on Overall Assessment

\begin{tabular}{|c|c|c|}
\hline & Frequency & $\%$ \\
\hline From locally owned banks & 149 & 43.6 \\
\hline From foreign owned banks & 17 & 5 \\
\hline Both & 172 & 50.3 \\
\hline None & 4 & 1.2 \\
\hline Total & 342 & 100 \\
\hline
\end{tabular}

Source: Primary Data 
The scenario represented by data in Table 4.10(a) reveals that the respondents had a high preference of locally owned banks (43.6\%) as compared with foreign owned banks $(5 \%)$. Moreover half of the respondents $(50.3 \%)$ would prefer both and $1.2 \%$ would not prefer any of the choices provided. However $98.1 \%$ of the respondents had multiple accounts in different banks.

\section{Consumer Ethnocentrism and the Willingness to Buy Banking Services}

The first objective of the study was to establish the relationship between consumer ethnocentrism and the willingness to buy banking services. The replication of this objective from the previous studies was imperative in order to test the validity of CETSCALE in Kenyan mixed economy contrary to their application in ex-communist economies. This objective was achieved by testing hypothesis one:

\section{$\mathrm{H}_{1}$ : Consumer ethnocentrism has significant influence on willingness to buy} banking services in Kenya.

The model proportional by chance accuracy was computed as shown in classification Table 1(a).

Table 1(a) Proportional by chance Accuracy Classification Table

\begin{tabular}{|c|c|c|c|c|}
\hline \multirow{3}{*}{\multicolumn{2}{|c|}{ Observed }} & \multicolumn{3}{|c|}{ Predicted } \\
\hline & & \multicolumn{2}{|c|}{$\begin{array}{l}\text { Willingness to buy banking } \\
\text { services }\end{array}$} & \multirow[b]{2}{*}{$\begin{array}{l}\text { Percentage } \\
\text { Correct }\end{array}$} \\
\hline & & $\begin{array}{c}\text { No } \\
\text { Preference }\end{array}$ & $\begin{array}{l}\text { Local } \\
\text { preference }\end{array}$ & \\
\hline \multirow{2}{*}{$\begin{array}{c}\text { Willingness to } \\
\text { buy banking } \\
\text { services }\end{array}$} & No Preference & 172 & 0 & 100.0 \\
\hline & Local preference & 166 & 0 & 0.0 \\
\hline \multicolumn{2}{|c|}{ Overall Percentage } & & & 50.9 \\
\hline
\end{tabular}

Source: Primary data

The data in Table 1(a) reveals that the proportional by chance accuracy rate for the expected model is $50.9 \%$. To determine the level of significance for the logistic regression model Omnibus test was done and the results are presented in Table 1(b).

Table 1(b) Omnibus Tests of Model Coefficients

\begin{tabular}{|c|c|c|c|}
\hline & Chi-square & df & Sig. \\
\hline Step & 30.601 & 1 & .000 \\
\hline Block & 30.601 & 1 & .000 \\
\hline Model & 30.601 & 1 & .000 \\
\hline
\end{tabular}

Source: Primary data.

As further shown in Table 1(b) the probability of the model chi-square is 30.601 and its $p$ value is $<0.001$ which is less than the level of significance of 0.05 . Therefore the study fails to reject $\mathrm{H}_{1}$. Thus the existence of a 
relationship between consumer ethnocentrism and willingness to buy banking services was supported. The relationship model summary is presented in Table 1(c).

Table 1(c) Model Summary

\begin{tabular}{|c|c|c|}
\hline-2 Log likelihood & Cox \& Snell R Square & Nagelkerke R Square \\
\hline $437.860^{\mathrm{a}}$ & .087 & .115 \\
\hline
\end{tabular}

Source: Primary data

Cox and Snell $\mathrm{R}^{2}$ and Nagelkerke's $\mathrm{R}^{2}$ values in Table 1(c) are less than 1. Hosmer and Lemeshow test was also done and the corresponding $\mathrm{p}$ value is greater than 0.05). These results therefore indicate a satisfactory goodness of fit. The smaller the likelihood value the better the goodness of fit. The classification accuracy compares predicted group membership based on the logistic model to the actual known group membership which is the value for the dependent variable. The actual accuracy of the model is presented in classification Table 1(d).

Table 1(d) Actual Accuracy Classification Table

\begin{tabular}{|c|c|c|c|c|}
\hline \multirow{2}{*}{} & \multicolumn{3}{|c|}{ Predicted } \\
\cline { 2 - 4 } & \multicolumn{2}{|c|}{$\begin{array}{c}\text { Willingness to buy } \\
\text { banking services }\end{array}$} & \multirow{2}{*}{$\begin{array}{c}\text { Percentage } \\
\text { Correct }\end{array}$} \\
\cline { 2 - 5 } & $\begin{array}{c}\text { No } \\
\text { Preference }\end{array}$ & $\begin{array}{c}\text { Local } \\
\text { preference }\end{array}$ & 68.0 \\
\hline $\begin{array}{c}\text { Observed } \\
\text { Willingness to } \\
\text { buy banking } \\
\text { services }\end{array}$ & No Preference & 117 & 55 & 62.7 \\
\cline { 2 - 5 } & $\begin{array}{c}\text { Local } \\
\text { preference }\end{array}$ & 62 & 104 & 65.4 \\
\hline \multicolumn{2}{|c|}{ Overall Percentage } & & & \\
\hline \multicolumn{2}{|c|}{ The cut value is .500 } & & & \\
\hline
\end{tabular}

Source: Primary Data

As can be discerned in Table 1(d) the utility of the logistic regression model is 65.4\%. Following the guidelines of Hair et al., (2006) the classification accuracy should be at least one-fourth ( 25 percent) greater that the hit ratio (proportional by chance accuracy), calculated at $50.9 \%$. Specifically the validation of the holdout sample should be at least $63.6 \%$ (1.25 x 50.9). The criterion for classification is therefore satisfied since the classification accuracy surpassed the proportional by chance criteria which support the utility of the model. Thus the model makes a correct prediction $65.4 \%$ of the time overall. To determine the logistic equation coefficients the probabilities of the Wald statistic were computed and the results are as shown in Table 1(e).

Table 1(e) Variables in the Equation

\begin{tabular}{|c|c|c|c|c|c|c|}
\hline & B & S.E. & Wald & df & Sig. & Exp(B) \\
\hline $\begin{array}{c}\text { Consumer } \\
\text { ethnocentrism }\end{array}$ & .778 & .149 & 27.304 & 1 & .000 & 2.176 \\
\hline Constant & -2.204 & .431 & 26.195 & 1 & .000 & .110 \\
\hline
\end{tabular}


As presented in Table 4.12(e) the independent variable standard error is less than 2.0 and hence there is no indication of multicollinearity. The probability of the Wald statistic for the variable is $<0.001$ which is less than the level of significance of 0.05 . The binary logistic regression equation that estimates the level of willingness to buy banking services is therefore stated as:

In $\mathrm{WB}=-2.204+0.778 \mathrm{CET}$

Where:

In $\mathrm{WB}=$ Natural logarithm of willingness to buy banking services

$\beta_{0}=-2.204$ (Intercept constant)

$\beta_{1}=0.778$ (Logistic régression coefficient)

CET $=$ Composite index of Consumer ethnocentrism

The value of $\operatorname{Exp}(\mathrm{B})\left(\mathrm{e}^{0.778}\right)$ is 2.176 which imply the probability that willingness to buy banking services equals 1 is twice as likely (2.176 times) as the value of consumer ethnocentrism is increased by one unit. The overall binary logistic regression also show that a one unit increase in consumer ethnocentrism decreases the odds that survey respondents had willingness to buy banking services from commercial banks in Kenya.

\section{Effect of Consumer Demographic Characteristics on the Willingness to Buy Banking Services}

The second objective of the study was to assess the effect of consumer demographic factors on the willingness to buy banking services. The following hypothesis was tested to achieve the objective:

$\mathrm{H}_{2}$ : Demographic factors have significant influence on willingness to buy banking services.

The proportional by chance accuracy for the logistic regression model was computed as shown in classification Table 2(a).

Table 2 (a) Proportional by Chance Accuracy Classification Table

\begin{tabular}{|c|c|c|c|c|}
\hline \multirow{2}{*}{\multicolumn{2}{|c|}{\begin{tabular}{c} 
Observed \\
\cline { 2 - 4 }
\end{tabular}}} & \multicolumn{2}{|c|}{$\begin{array}{c}\text { Predicted } \\
\text { Willingness to buy banking } \\
\text { services }\end{array}$} & \multirow{2}{*}{$\begin{array}{c}\text { Percentage } \\
\text { Correct }\end{array}$} \\
\cline { 2 - 5 } & $\begin{array}{c}\text { No } \\
\text { Preference }\end{array}$ & $\begin{array}{c}\text { Local } \\
\text { preference }\end{array}$ & 100.0 \\
\hline $\begin{array}{c}\text { Willingness to } \\
\text { buy banking } \\
\text { services }\end{array}$ & $\begin{array}{c}\text { No } \\
\text { Preference }\end{array}$ & 147 & 0 & 0.0 \\
\cline { 2 - 5 } & $\begin{array}{c}\text { Local } \\
\text { preference }\end{array}$ & 145 & 0 & 50.3 \\
\hline \multicolumn{2}{|c|}{ Overall Percentage } & & & \\
\hline
\end{tabular}

Source: Primary data. 
The information in Table 2(a) indicates that the proportional by chance accuracy rate for the expected model is $50.3 \%$. To determine the level of significance Omnibus tests was done and the results are presented in Table 2(b).

Table 2(b) Omnibus Tests of Model Coefficients

\begin{tabular}{|c|c|c|c|}
\hline & Chi-square & df & Sig. \\
\hline Step & 16.126 & 9 & .064 \\
\hline Block & 16.126 & 9 & .064 \\
\hline Model & 16.126 & 9 & .064 \\
\hline
\end{tabular}

Source: Primary Data.

As shown in Table 2(b) the probability of the model chi-square is 16.126 and $p$ value of 0.064 which is greater than the level of significance of 0.05 . Hence the study rejects $\mathrm{H}_{2}$. Hence the relationship between demographic characteristicss and willingness to buy banking services do not exist. However further statistical analysis show different results. The model summary is as shown in Table 2(c).

Table 2(c) Model Summary

\begin{tabular}{|c|c|c|}
\hline-2 Log likelihood & Cox \& Snell R Square & Nagelkerke R Square \\
\hline 388.658 & .054 & .072 \\
\hline
\end{tabular}

Source: Primary Data.

The Cox and Snell $\mathrm{R}^{2}$ and Nagelkerke's $\mathrm{R}^{2}$ values in Table 2(c) are less than 1. Hosmer and Lemeshow test was also computed and the $p$ value is greater than 0.05 .Therefore the results indicate satisfactory goodness of fit for the logistic regression model. To assess the actual accuracy of the logistic regression model the classification accuracy test was computed and the results are as shown in Table 2(d).

Table 2(d) Actual accuracy Classification Table

\begin{tabular}{|c|c|c|c|c|}
\hline \multirow{2}{*}{\multicolumn{2}{|c|}{ Observed }} & \multicolumn{3}{c|}{ Predicted } \\
\cline { 2 - 4 } \multicolumn{2}{|c|}{} & $\begin{array}{c}\text { Willingness to buy banking } \\
\text { services }\end{array}$ & \multirow{2}{*}{$\begin{array}{c}\text { Percentage } \\
\text { Correct }\end{array}$} \\
\cline { 2 - 4 } & $\begin{array}{c}\text { No } \\
\text { Preference }\end{array}$ & $\begin{array}{c}\text { Local } \\
\text { preference }\end{array}$ & \\
\hline $\begin{array}{c}\text { Willingness to } \\
\text { buy banking } \\
\text { services }\end{array}$ & No Preference & 67 & 80 & 45.6 \\
\cline { 2 - 5 } & Local preference & 39 & 106 & 73.1 \\
\hline \multicolumn{2}{|c|}{ Overall Percentage } & & & 59.2 \\
\hline
\end{tabular}

Source: Primary Data

As presented in Table 2(d), the model utility is $59.2 \%$ which is less than the proportional by chance accuracy criteria of $62.9 \%(1.25 \times 50.3)$. The criterion for classification is not satisfied therefore the model cannot be relied upon in order to make correct predictions. To establish the logistic regression 
equation coefficients the probabilities of the Wald statistic were computed and the results are shown in Table 2(e).

Table 2(e) Variables in the Equation

\begin{tabular}{|c|c|c|c|c|c|c|}
\hline & B & S.E. & Wald & df & Sig. & $\operatorname{Exp(B)}$ \\
\hline Age & & & 8.213 & 3 & .042 & \\
\hline $18-25$ years & -.936 & .509 & 3.389 & 1 & .066 & .392 \\
\hline $26-32$ years & -.200 & .396 & .254 & 1 & .614 & .819 \\
\hline $33-40$ years & .436 & .378 & 1.331 & 1 & .249 & 1.546 \\
\hline Gender & .159 & .247 & .418 & 1 & .518 & 1.173 \\
\hline Income & & & 10.796 & 4 & .029 & \\
\hline Up to Ksh 10,000 & 1.902 & .605 & 9.893 & 1 & .002 & 6.698 \\
\hline Ksh 10,000 - 20,000 & 1.301 & .594 & 4.794 & 1 & .029 & 3.673 \\
\hline Ksh 20,001-50,000 & 1.010 & .437 & 5.333 & 1 & .021 & 2.745 \\
\hline Ksh 50,001-100,000 & .946 & .416 & 5.181 & 1 & .023 & 2.577 \\
\hline Constant & -.474 & .844 & .315 & 1 & .574 & .623 \\
\hline
\end{tabular}

Source: Primary Data

As shown in 2(e) the standard errors for all independent variables are less than 2.0 and as such there is no indication of multicollinearity. The probabilities of the Wald statistic for age, gender and religion are greater than the level of significance of 0.05 . However, the probabilities of the Wald statistic for the levels of income per month are less than the level of significance of 0.05 . Hence results indicate a significant relationship between the levels of income and the willingness to buy banking services. Hence the study fails to reject $\mathrm{H}_{2}$. The logistic regression equation is therefore stated as:

$\mathrm{In} \mathrm{WB}=-0.474+1.902 \mathrm{I} 1+1.301 \mathrm{I} 2+1.01 \mathrm{I} 3+0.946 \mathrm{I} 4$

Where:

In WB = Natural logarithm of willingness to buy banking services

$\beta_{0}=-0.474$ (Intercept constant)

$\beta_{1}=1.902 ; \beta_{2}=1.301$;

$\beta_{3}=1.01 ; \beta_{4}=0.946$ (Logistic régression coefficients)

$\mathrm{I}_{1}=\mathrm{Up}$ to $\mathrm{Ksh} 10,000$;

$\mathrm{I}_{2}=$ Ksh $10,001-20,000$

$\mathrm{I}_{3}=\mathrm{Ksh} 20,001-50,000$

$\mathrm{I}_{4}=\mathrm{Ksh} 50,001-100,000$

The corresponding Exp (B) values are $6.698\left(\mathrm{e}^{1.902}\right), 3.673\left(\mathrm{e}^{1.301}\right)$, $2.745\left(\mathrm{e}^{1.01}\right)$ and $2.577\left(\mathrm{e}^{0.946}\right)$ respectively which implies:

i) The probability that willingness to buy banking services equals 1 is seven times (6.698) as likely as the levels of income among the respondents currently earning below Ksh 10,000 is increased by one unit.

ii) The probability that willingness to buy banking services equals 1 is four times (3.673) as likely as the levels of income among the respondents currently earning between Ksh 10,001 - 20,000 is increased by one unit. 
iii) The probability that willingness to buy banking services equals 1 is three times (2.745) as likely as the levels of income among the respondents currently earning between Ksh 20,001 - 50,000 is increased by one unit.

iv) The probability that willingness to buy banking services equals 1 is three times (2.577) as likely as the levels of income among the respondents currently earning below Ksh 50,001 - 100, 000 is increased by one unit.

Overall, the results indicate that a one unit increase in levels of income decreases the odds that survey respondents had in willingness to buy banking services from commercial banks in Kenya. Hence the tendency to prefer local or foreign commercial banking services was highly influenced by the respondents' level of income.

\section{Consumer Ethnocentrism, Demographic characteristics and Willingness to Buy Banking Services}

The third objective was to assess the moderating effect of consumer demographic factors on the relationship between consumer ethnocentrism and willingness to buy banking services. The hypothesis three was tested in order to achieve the objective:

$\mathrm{H}_{3}$ : Demographic factors have significant moderating effect on the relationship between consumer ethnocentrism and willingness to buy banking services.

The moderating effect of the demographic characteristics including gender, age and income was tested using stepwise binary logistic regression. However none of these variables were significant when the Wald statistic test was conducted. Therefore the three demographic factors do not moderate the relationship between consumer ethnocentrism and willingness to buy banking services. These findings contradict Josiassen et al., (2011). However the moderating effect of demographic factors may vary depending on the product type or country where the study was conducted. Also some market environmental factors may affect a specific consumer group and not necessarily the entire population. This is evident by the findings of the study which showed a joint effect of consumer ethnocentrism and demographic factors on the willingness to buy banking services among the youth aged 18 25 years. Therefore consumer ethnocentrism construct should not be limited to the country as whole but to specific social groups within a country.

\section{Conclusion}

Several conclusions may be made based on the study results. Consumer ethnocentrism was found to have a negative influence on willingness to buy banking services from foreign owned commercial banks. Hence the level of localization adopted by the commercial banks can influence consumer choice behaviour. Subsequently although the study's findings did 
not show any moderating influence of all demographic factors on the relationship between consumer ethnocentrism and willingness to buy banking services, the role of such factors needs to be investigated further. The direct influence of levels of income was found to have a strong effect on the consumer willingness to buy banking services in Kenya. Consumers with lower levels of income preferred to buy from locally owned commercial banks and vice versa. This indicated the essence of intergroup differentiation in service or market offerings as well as market segmentation and targeting.

\section{Managerial Implications}

Consumer ethnocentrism was found to have a negative influence on the willingness to buy banking services from foreign owned banks. Based on the these findings foreign investors in the banking industry should have pertinent localization strategies incorporated in their broad corporate strategies. This will not only guide the banks in repositioning their products in the domestic markets but also in adapting their operations in order to enhance domestic consumption. Hence foreign commercial banks can maintain their bargaining strength by developing local support systems. They can satisfy their own objectives and find local acceptability by implementing activities that consistently and openly explain their business behavior as well as by developing product lines specifically for local demand. The spirit of nationalism can be counteracted if the foreign commercial banks develops localized image to avoid falling victim.

\section{References:}

Ajzen, I., (1987). Attitudes, traits, and actions: Dispositional prediction of behavior in personality and social psychology. In L. Berkowitz (Ed.), Advances in experimental social psychology (Vol. 20, pp. 1-63). New York: Academic Press.

Anderson, W.T. \& Cunningham, W.H., (1972). Gauging foreign product promotion. Journal of Advertising Research, February, pp.29-34.

Baker, J., Levy, M., \& Grewal, D., (1992). An experimental approach to making retail store environmental decisions. Journal of Retailing, Vol. 68, pp. 445-60.

Balabanis, G., Diamantopoulos, A. \& Mueller, R., (2001). The impact of nationalism,patriotism and internationalism on consumer ethnocentric tendencies. Journal of International Business Studies, Vol. 32(1), pp.157-75. Balabanis, G. \& Diamantopoulos, A., (2004). Domestic country bias, countryof-origin effects, and consumer ethnocentrism: a multidimensional unfolding approach. Journal of the Academy of Marketing Science, Vol. 3(1). 
Bandyopadhyay, S., Wongtada, N., \& Rice, G., (2011). Measuring the impact of inter-attitudinal conflict on consumer evaluations of foreign products. Journal of Consumer Marketing, Vol. 28 Iss: 3, pp.211 - 224.

Bannister, J.P. \& Saunders, J.A., (1978). UK consumers' attitudes towards imports:the measurement of national stereotype image. European Journal of Marketing, Vol. 12.

Baron, R. M., \& Kenny, D. A., (1986). The moderator-mediator variable distinctionin social psychological research: Conceptual, strategic and statistical considerations. Journal of Personality and Social Psychology, 51, 1173-1182.

Caruana, A., (1996). The effects of dogmatism and social class variables on consumer ethnocentrism in Malta. Marketing Intelligence \& Planning, Vol. 14 (4) pp.39.

Chattalas, M., Kramer, T.\& Takada, H., (2008). The impact of national stereotypes on the Country of origin effect: a conceptual framework. International Marketing Review, Vol. 25(1)

Chryssochoidis, G., Krystallis, A. \& Perreas, P., (2007). Ethnocentric beliefs and country of origin effect: impact of country, product, and product attributes on Greek consumers' evaluation of food products. European Journal of Marketing, Vol. 41

Cronbach, L. J., (1951). Coefficient alpha and the internal structure of tests. Psychometrika, 16, 297.

Erdogan, B. Z. \& Uzkurt, C., (2010). Effects of ethnocentric tendency on consumers' perception of product attitudes for foreign and domestic products. Cross Cultural Management: An International Journal, Vol. 17 Iss: 4, pp.393 $-406$

Field, A., (2005). Discovering Statistics Using SPSS. Sage, London.

Good L. K. \& Huddleston, P. (1995). Ethnocentrism of Polish and Russian consumers: Are feelings and intentions related? International Marketing Review, 12.

Hair, J., Black, W., Babin, B., Anderson, R., \& Tatham, R., (2006). Multivariate Data Analysis, 6th ed. Prentice-Hall, Upper Saddle River, NJ. Han, C.M., (1988). The role of consumer patriotism in the choice of domestic versusforeign products. Journal of Advertising Research, June/July, pp.25 32.

Hosmer, D. \& Lemeshow, S., (2000). Applied Logistic Regression. $2^{\text {nd }}$ ed., NY:Wiley \& Sons.

Jaccard, J., Turrisi, R., \& Wan, C., (1990). Interaction Effects in Multiple Regression, Sage, Beverly Hills, CA.

Jaccard, J., (2001). Interaction effects in logistic regression. Thousand Oaks, CA: Sage Publications. Quantitative Applications in the Social Sciences Series, No. 135. 
Josiassen, A., Assaf, G. \& Karpen, I., (2011). Consumer ethnocentrism and willingness to buy: Analyzing the role of three demographic consumer characteristics. International Marketing Review, Vol. 28 (6), pp.627 - 646.

Klein, J.G.\& Ettenson, R., (1999). Consumer animosity and consumer ethnocentrism: An analysis of unique antecedents. Journal of International Consumer Marketing,Vol. 11 No.4, pp.5-24.

Morrison, D. G., (1979). Purchase Intentions and Purchase Behavior. Journal of Marketing, 43(Spring), 65-74.

Nishina, S., (1990). Japanese consumers: introducing foreign products/brands into the Japanese market. Journal of Advertising Research, April/May, pp.3545.

Nunnally, J. \& Bernstein, I., (1994). Psychometric Theory. New York: McGraw Hill.

Power, C. \& Elliott, J., (2006). Cohort profile: 1958 British Cohort Study. International Journal of Epidemiology 35 (1): 34-41

Triandis, H.C., Leung, K., Villareal, M.J., \& Clack, F.L. (1985). Allocentric versus idiocentric tendencies: convergent and discriminant validation. Journal of Research in Personality, Vol. 19 pp.395-415.

Schooler, R.D., (1971). Bias phenomena attendant to the marketing of foreign goods in the US. Journal of International Business Studies, Vol. 2 pp.71-80.

Shankarmahesh, M., (2006). Consumer ethnocentrism: an integrative review of its antecedents and consequences. International Marketing Review, Vol 23 (2).

Sharma, S., Shimp, T. \& Jeongshin, S., (1995). Consumer ethnocentrism: a test of antecedents and moderators. Journal of the Academy of Marketing Science, Vol. 23 No.1.

Sharma, P., (2011). Country of origin effects in developed and emerging markets: exploring the contrasting roles of materialism and value consciousness. Journal of International Business Studies, Vol. 42 (2), pp.285306.

Shimp, T.\& Sharma, S., (1987). Consumer ethnocentrism: construction and validation of the CETSCALE. Journal of Marketing Research, Vol. 24 No.3, pp.280-9.

Tan, C. \& Farley, J., (1987). The impact of cultural patterns on cognition and intention in Singapore. Journal of Consumer Research, Vol. 13 pp.540-4.

Wang, C. \& Chen, Z., (2004). Consumer ethnocentrism and willingness to buy domestic products in a developing country setting: testing moderating effects. Journal of Consumer Marketing, Vol. 21 (6), pp.391-400. 